\title{
Errattum to: Assessment of Energy Metabolic Changes in Adipose Tissue-Derived Stem Cells
}

Ghazaleh Hajmousa and Martin C. Harmsen

\section{Erratum to:}

Chapter 5 in: Paolo Di Nardo et al. (eds.), Adult Stem Cells:

Methods and Protocols, Methods in Molecular Biology, vol. 1553, DOI 10.1007/978-1-4939-6756-8_5

In Chapter 5 titled "Assessment of Energy Metabolic Changes in Adipose TissueDerived Stem Cells", the authors have added acknowledgement text to read as follows:

This project has received funding from the Marie Curie International Research Staff Exchange Scheme with the 7th European Community Framework Program under grant agreement No. 295185 - EULAMDIMA. 